\author{
MARIA WACŁAWEK \\ (D) https://orcid.org/0000-0002-3307-5338 \\ Univerza $v$ Ljubljani \\ Lublana \\ MARIA WTORKOWSKA \\ (D) https://orcid.org/0000-0001-9317-2490 \\ Univerza $v$ Ljubljani \\ Lublana
}

\title{
Słoweniec jako wieczny student i nie tylko - wycinek z polsko-słoweńskich badań ankietowych
}

\author{
Slovenians as eternal students and not only \\ - excerpt from a Polish-Slovenian survey
}

\begin{abstract}
The educational system in a given country largely influences the process of shaping of the students' identity. The text is a study on an excerpt from material which is part of research reconstructing the linguistic and cultural image of Poles and of Slovenians. An analysis of the operational categories of the linguistic image of the world is a valuable source of knowledge about the stereotypical image of the country and of its representatives, reflecting the subjective point of view of respondents. A binary model emerges clearly, with a positive - negative (unambitious) attitude of Slovenians towards science and education. The comparison of the auto- and heterostereotypical approach, in our case the Slovenian one with the Polish one (respondents who had had contact with Slovenians), yields a broader picture of the studied aspect.

Key words: educational system, learning, education, stereotypes, linguistic image of the world, Slovenian
\end{abstract}

Szkolnictwo danego kraju ma ogromny wpływ na kształtowanie tożsamości uczących się. Rajko Nahtigal ${ }^{1}$ - słoweński slawista, naukowiec i pedagog - wiele lat temu podkreślał znaczenie prowadzenia badań we własnym (sło-

\footnotetext{
${ }^{1}$ Rajko Nahtigal (1877-1958) był pierwszym dziekanem Wydziału Filozoficznego Uniwersytetu w Lublanie, później rektorem tej uczelni, a także pierwszym przewodniczącym lublańskiej Akademii Nauk i Sztuk.
} 
weńskim) języku oraz traktowania tego typu dociekań jako obowiązku wobec swojej kultury i narodu: ,izvira za vsak narod, ki se povzpne do takega [kulturnega] nivoja, kulturna dolžnost storiti za občno kulturo vsaj to, da znanstveno kolikor mogoče preuči samega sebe, svojo zgodovino in svojo zemljo v vseh ozirih. (...) ima vsak narod dolžnost študija predvsem samega sebe in vsega, kar je njegovega" (Nahtigal 1927, 11). Wypowiedź ta nabiera szczególnego wymiaru wobec faktu, że początki odrębności państwowej Słowenii datuje się na rok 19912, a w bieżącym 2019 roku Uniwersytet w Lublanie obchodzi stulecie swojego istnienia 3 .

Od wieków rozmyślano o celach edukacji, wykształcenia i wychowania. Terminy te (tak w polszczyźnie, jak i w języku słoweńskim, por. słń.: ₹nanost, edukacija, znanje, izobraževanje, izobraženost, izobraz̧a, vagoja) zawieraja wiele elementów wspólnych, a także różniących się. Dla potrzeb artykułu istotne będzie między innymi pojęcie sžkolnictwa, rozumianego jako system zorganizowanych form wychowania i kształcenia, umożliwiający zdobycie określonego stopnia lub typu wykształcenia (Medveš 1999, 13, 85), które może różnić się w zależności od kraju. Niniejszy tekst służy rekonstrukcji wycinka stereotypowego i językowo-kulturowego wyobrażenia Słoweńców dotyczącego ich stosunku do nauki i wykształcenia. Przy opracowaniu materiału pomocna okazała się metodologia językowego obrazu świata, w tym stereotypu, rozumianego w myśl entolingwistyki kognitywnej jako nacechowane antropocentryzmem, subiektywne, symplifikujące oraz mające określony punkt widzenia i związaną z tym perspektywę (Bartmiński 2007; 2009) „wyobrażenie utrwalone w potocznym, obiegowym wariancie języka ogólnopolskiego, stojące między wyrażeniem językowym a realnym światem" (Bartmiński, Bielińska-Gardziel 2012, 10). Funkcje stereotypu jako konceptu opisowego i wartościującego są zakorzenione w podstawowych mechanizmach postrzegania i interpretacji rzeczywistości (Bartmiński 2007, 230).

Poddany analizie materiał językowy pochodzi z odpowiedzi na pytanie o stosunek do nauki i wykształcenia w Słowenii, wchodzące w skład ankiety na temat stereotypowego obrazu Polaków i Słoweńców, wypełnionej przez

2 Do tego czasu (od 1945 roku) Słowenia funkcjonowała w obrębie Socjalistycznej Federacyjnej Republiki Jugosławii.

3 W nowo powstałym uniwersytecie 3.12.1919 roku wykład inauguracyjny na temat gramatyki historycznej języka słoweńskiego wygłosił językoznawca i dialektolog Fran Ramovš (1890-1952). Wydarzenie to świadczy o tym, jak wielką rolę odgrywał Wydział Filozoficzny w misji wyznaczonej w tamtych czasach przez uniwersytet, a mianowicie w umożliwieniu studiów i badań naukowych w języku słoweńskim. 
140 respondentów (70 z Polski i tyluż ze Słowenii), którzy mają kontakt lub znają przedstawicieli drugiej narodowości. Niniejsze opracowane stanowi zatem fragment większych badań ${ }^{4}$. Ankietowani, wybrani zgodnie z dostępnością, to reprezentanci różnych grup wiekowych, ze znaczną przewagą kobiet mających wyższe wykształcenie. Kwestionariusz wypełniano w języku rodzimym. $\mathrm{Na}$ wszystkie wypowiedzi dotyczące słoweńskiego nastawienia do edukacji i wykształcenia składają się 422 ekscerpty (226 słoweńskich i 196 polskich wyimków) ${ }^{5}$. Badania auto- i heterostereotypu, a więc tego, jak reprezentanci danej grupy (tu słoweńskiej) widzą i oceniają samych siebie (A) oraz tego, jak postrzegaja ich inni (przykładowi polscy badani - H), sa istotne - porównanie obu ujęć pozwoli na odtworzenie pełniejszego obrazu, uwzględniającego podobieństwa i rozbieżności w ilościowym i jakościowym podziale analizowanego materiału 6 . W opisie brałyśmy pod uwage także cechy werbalizowane jedynie w jednokrotnych przykładach, uznając je za cenne (Bartmiński 2007, 90). Udział procentowy wyodrębnionych grup tematycznych w ramach kategorii 'stosunek Słoweńców do nauki i wykształcenia' przedstawia się następująco: 1) pozytywny (A - 50\%, H - 63\%), 2) negatywny $(\mathrm{A}-47 \%, \mathrm{H}-29 \%)$ i 3$)$ inne $(\mathrm{A}-3 \%, \mathrm{H}-8 \%)$.

\section{Pozytywny stosunek Słoweńców do nauki i wykształcenia}

Duża grupa poświadczeń, liczniejsza w heterostereotypie, współtworzy model pozytywnego postrzegania stosunku Słoweńców do nauki i wykształcenia (A - 50\%, H - 63\%). Tabela 1 zbiera wyodrębnione klasy tematyczne.

${ }^{4}$ Niektóre ankietowe zagadnienia zostały już opracowane, przedstawiają wyniki dotyczące między innymi kategorii: wygląd, charakter, sposoby spędzania wolnego czasu, kulinaria (por.: Wacławek, Wtorkowska 2017a-c; 2018a-c; 2019a-d). Planowana jest osobna całościowa monografia, szczegółowo przedstawiająca metodologię, podsumowująca dotychczasowe publikacje i przedstawiająca pozostałe wyróżnione przez autorki kategorie tematyczne odtwarzanych stereotypowych wyobrażeń (modeli).

5 Suma wszystkich wyimków (W) zebranych w danym ujęciu (autostereotyp/heterostereotyp) stanowi wartoś ć100\%, czyli $\mathrm{W}_{\mathrm{A}}=226, \mathrm{~W}_{\mathrm{H}}=196$.

${ }^{6}$ Ze względu na to, że badamy modelowe wyobrażenie Słoweńców, w określonej grupie słoweńskich i polskich respondentów, rekonstruowany symplifikujący obraz odnosi się tylko do osób objętych badaniem, nie można go uogólniać na całą społeczność obu narodów. Tylko w takim znaczeniu na potrzeby niniejszego tekstu będziemy używać nazw auto- i heterostereotyp. 
Tabela 1. Klasy w pozytywnym stosunku Słoweńców do nauki (\%)

\begin{tabular}{|l|r|r|}
\cline { 2 - 3 } \multicolumn{1}{c|}{} & A & H \\
\hline Ogólne - różne & 22,0 & 17,0 \\
\hline Pozytywne cechy wykształconego/kształcącego się & 10,0 & 26,0 \\
\hline Popularność studiów & 7,5 & 2,5 \\
\hline Pochwała szkolnictwa i wykładowców & 7,0 & 4,5 \\
\hline Znajomość języków obcych & 3,0 & 7,0 \\
\hline Cenienie umiejętności praktycznych & 0,5 & 1,5 \\
\hline Dwukierunkowość studiów & 0,0 & 2,5 \\
\hline Studia jako pomoc w karierze & 0,0 & 2,0 \\
\hline Razem & 50,0 & 63,0 \\
\hline
\end{tabular}

W klasie określeń ‘ogólne - różne' liczniejsze i bardziej zróżnicowane okazały się wypowiedzi ankietowanych rodaków Petera Prevca (A - 22\%); w ujęciu heterostereotypowym (polskim) stanowią one 17\%, co w grupie 'pozytywny stosunek Słoweńców do edukacji i wykształcenia' plasuje omawianą klasę na drugim miejscu pod względem liczebności.

Przedstawiciele obu nacji biorących udział w ankiecie rzadko jednak wprost oceniaja stosunek do nauki i wykształcenia w Słowenii jako pozytywny i bardzo dobry (A - 2\%, H - 3\%): splošno gledano je odnos pozitiven; bardzo pozytywny; pozytywny. Zarówno słoweńscy, jak i polscy respondenci zauważyli, że nauka i wykształcenie są dla Słoweńców ważne, stanowią istotną wartość (A - 9\%, H - 6\%), co werbalizowano głównie za pomoca często używanego przymiotnika ważny (słń. pomemben): izobrazba je pomembna; izobrazba kot pomembna vrednota; wykształcenie jest dla nich ważne; nauka jest bardzo ważna. W autostereotypowych egzemplifikacjach nierzadko dodatkowo podkreślano wage osiągnięć naukowych ${ }^{7}$, zarówno opisanych ogólnie: izobraz̧ba in dosežki so nam zelo pomembni, jak i tych przedstawionych konkretnie - głównie dotyczących badań jądrowych, nauk przyrodniczych i osiagnięć techniki, a także obróbki drewna - sukcesy uznawane za narodowe, słoweńskie („nasze”) i zdaniem respondentów w opinii publicznej określane jako coś wspaniałego (niewiarygodnego): veliki dosežki v znanosti, np. CERN, inštitut Jozefa Stefana, lesarstvo; vsak slovenski znanstveni napredek oz. izum je predstavljen sirši javnosti kot nekaj neverjetnega. Ujawnione w autostereotypie podmiotowy punkt widzenia i takaż perspektywa oceniane in plus nie zaskakują (Bartmiński 2009, 78-79).

Dane językowe zebrane z ankiet świadczą o tym, że Słoweńcy cenią sobie naukę, wiedzę i wykształcenie, kładąc na nie duży nacisk i wspierając je -

7 Tego typu ekscerpty w omawianej podklasie stanowią $2 \%$ z 9\%. 
również finansowo (A $-5 \%, \mathrm{H}-3 \%$ ). Językowo wyrażane było to za pomocą czasowników cenić (słń. ceniti), doceniać, w słoweńskich wyimkach również dać - w znaczeniu 'łożyć na coś' (słń: dati): znanost in izobrazbo se močno ceni; veliko damo na izobrazbo in visoko solstvo; ceniq wiedze $i$ wykesztatcenie. Pozytywny stosunek do nauki i wykształcenia w Słowenii bywał wyrażany za po-

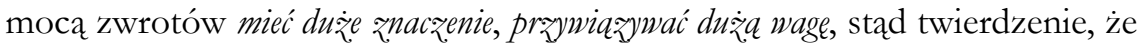
nauka i wykształcenie mają w Słowenii duże znaczenie (słń. veliki pomen), traktuje się je poważnie i przywiązuje się do nich dużą wagę (A - 3\%, $\mathrm{H}-3 \%$ ): znanost in izobrazba imata na Slovenskem velik pomen; dużq wage praywiazuja do nauki i wyksztatcenia.

Szacunkiem darzony jest nie tylko system edukacji: spoštujejo izobrazbo; myśle, że średnia generacja bardzo sqanuje wyksz̧tałcenie, ale również osoby wykszta1cone, w szczególności posiadające tytuł naukowy (A - 3\%, H - 2\%): s strani družbe so diplomanti in doktorji znanosti cenjeni; szacunek wobec ludzi wyksztatconych; co może być przez ludzi z zewnattrz odbierane niekiedy jako przesadne prezentowanie własnej wartości i/lub sposób sprawdzania wykształcenia nowo poznanej osoby: dopiero tutaj dowiedziatam sie, jaki „straszliwy bład” popelniam, nie przedstawiajac sie jako "magister" i nie majac na wizytówce wpisanego swojego tytułu nankowego; tytuł obowiqzkowy. Mieszkańcy tego malowniczego kraju zdaja sobie sprawę, że z wykształceniem wiąże się poważanie, reputacja i szacunek w społeczeństwie, dlatego jest ono w Słowenii pożądane i potrzebne: na splośno pa si ljudje želijo čim višjo izobraz̧bo, saj ta prinaša določen ugled v družbi (npr. naẓiv dr.).

Ekscerpty zakwalifikowane do klasy 'pozytywne cechy wykształconego lub kształcącego się Słoweńca’ okazały się najbardziej liczebne w ujęciu heterostereotypowym, a drugie pod względem liczebności w autostereotypie (A - 10\%, H - 26\%). Zarówno słoweńscy, jak i polscy respondenci zauważyli $(\mathrm{A}-5 \%, \mathrm{H}-2 \%)$, że Słoweńcy są:

- (wysoko, dobrze, bardzo, dosyć) wykształcenis: želo izobraženi; visoko izobraženi; prebivalstuo dobro izobraženo; dobrze wykształceni; Stoweńcy to wyksztatcony naród;

- pracowici, pilni, sumienni: pridni ljudje; sq pracowici; sq bardzo sumiennymi i pilnymi uczniami, studentami;

- ambitni: ambiciozni ljudje; sq ambitni; Stoweńcy wydaja sie ambitni;

- otwarci: se odpiramo v tujino; latwo ulegaja nowościom też w edukacji;

- kulturalni: Stoweńcy to kulturalny naród.

8 Wykształcony to cecha najczęściej wskazywana przez Polaków i Słoweńców, choć stwierdzenie: „cechą wykształconego czy kształcącego się Słoweńca jest to, że jest wykształcony” ujawnia tautologię. 
Wysoki odsetek polskich danych ankietowych dotyczy obrazu Słoweńca chętnie i dużo się uczącego (H - 17\%), co językowo wyrażane było za pomocą odpowiednich konstrukcji czasownikowych: Stoweńcy duг̃o sie uczq; lubia sie uczýc; chca się uczyć. Takiego stanu rzeczy raczej nie dostrzegli (albo językowo nie wskazywali) u siebie słoweńscy respondenci $(\mathrm{A}-1 \%$ ): radi se učmo. Chęć nauki najczęściej konceptualizowano w odniesieniu do studentów, którzy odbierani byli jako zainteresowani wybranymi kierunkami studiów, poważnie traktujący swoje obowiązki': studenci wydaja sie być zainteresowani przedmiotami, które podejmuja na studiach, obecność na zajeciach jest wysoka; podchodzi poważnie do tematu studiów, prayklełada sie do nauki; traktuja nauke poważnie. Model kształcącego się Słoweńca rysuje się bardzo pozytywnie - jako osoby z pasją, wybierającej studia świadomie, a nie tylko dla uzyskania dokumentu, gotowej ponieść wszelkie koszty edukacji, mającej duże wsparcie rodziców: gotowość ponoszenia kosztów edukacji wszelkiego typu. Akceptacja zwiazanych z tym wyrzeczeń; mam wrażenie, ìe sa to osoby, które studiuja dla siebie, a nie dla dokumentu. Jeśli już ida na wyketad cay ćmiczenia, to nie jest to prayjście po to, aby mieć obecność, ale po to, żeby jak najwiecej z. nich wynieśsíc; so pa tudi posamezniki, ki so dejavni na raziskovalnem področju, ki želijo iz̧boljšati svet in temu posvetijo ogromno svojega časa.

Zapał i chęć do nauki Słoweńców przekłada się na werbalizowana popularność studiów w Słowenii, co językowo częściej podkreślano w autostereotypie (A - 7,5\%, H - 2,5\%). Zgodnie z zarejestrowanymi ekscerptami obecnie dużo ludzi (większość młodych) podejmuje studia: večina mladih sedaj studira; vsi si ̌̌lijo studirati; danes studira vsak; studij je skorajda samoumeven; dus̆y odsetek ludzi mtodych decyduje sie na podjecie studiów.

Polscy ankietowani, i w jednostkowych przypadkach słoweńscy, językowo wyrazili pochwałę szkolnictwa i wykładowców w Słowenii (A - 7\%, H - 4,5\%), podkreślając posiadanie dobrych instytucji oświaty oraz wysoki poziom nauki: v Sloveniji je na voljo veliko dobrih institucij; dobre sole; veliko dobrih fakultet; szkolnictwo jest na wysokim poziomie. Uznanie dla nauczycieli akademickich wyrażono przez wyliczenie ich zalet - przystępność, otwartość, pomysłowość, profesjonalizm, pasja, zdolność zaciekawienia przedmiotem: zajecia sq bardzo ciekawe, uczeszrzaja na nie zprayjemnościa ale nieregularnie; profesorowie sa bardziej praystęni, otwarci dla studenta; wyktadowcy staraja sie zainteresować swoim przedmio-

\footnotetext{
${ }^{9}$ Tego typu ekscerpty w części heterostereotypowej omawianej podklasy stanowią 5\% z $17 \%$.

${ }^{10}$ Cytat ten można odczytać jako pozytywny odblask (odłamek) albo rewers modelu wiecznie studiującego Słoweńca, opisanego w części dotyczącej krytycznego stosunku do edukacji.
} 
tem, w wiekeszości wypadków widać pasje do nauczanego przedmiotu, a jeśli jej nie ma, to profesjonalizm $i$ pomystowość $w$ zróżnicowaniu zadan stawianych przed studentami (w praypadku zajéc prak.tycznych, w szczególności o charakterze filologicznym).

Jedynie słoweńscy respondenci ${ }^{11}$ dodatkowo wyrażają i pozytywnie oceniają inne (wydawać by się mogło oczywiste) aspekty systemu oświaty, jak jej ogólnodostępność i bezpłatność: visoko šlstvo je dostopno vsem; poudarja se splošna dostopnost do izobraz̧be in se zabteva brezplačno šlstvo czy fakt, że są dumni z edukacji i wykształcenia w swoim kraju, z jakoby najdłuższą historia kształcenia w Europie: v velik ponos jim je izobraženost, znanje; država z. najdaljsim izobraževanjem v Evropi.

W kontekście edukacji w Słowenii ankietowani pozytywnie ocenili znajomość języków obcych wśród przedstawicieli słoweńskiej nacji (A - 3\%, H - 7\%): dobri govorci tujih jezikov; bardzo dobra znajomość jezykón obych. Respondenci ze Słowenii wspomnieli o dobrej umiejętności posługiwania się językami innych republik byłej Jugosławii (szczególnie chorwackiego i serbskiego), co wynika z wieloletniego współfunkcjonowania w jugosłowiańskiej jedności państwowej: imajo tudi prednost $v$ znanju tujih jezikov sosednjih držav, $v$ glavnem srbohrvašcine. Zauważona i chwalona przeważnie przez polskich badanych jest bardzo dobra znajomość języka angielskiego, którym władaja prawie wszyscy Słoweńcy bez względu na wiek, wykształcenie i status społeczny: pogosto tekoce govorijo angleško; praybywajacych tu zdumiewa dobra znajomośc jezyka angielskiego (i innych jezylków) przedstawicieli właściwie każdej grupy wiekowej $i$ zawodowej; po angielsku można sie porozumié́ wszedzie, nawet z żebrzacymi bezdommymi çy tzw. babciami klozetowymi. Tak dobre opanowanie języków obcych Słoweńcy w dużej mierze zawdzięczają systemowi oświaty ${ }^{12}$, który wprowadził bezpłatną naukę języka angielskiego już w przedszkolach i pierwszych klasach szkół podstawowych (Krek, Metljak 2011, 34).

Wśród rzadko pojawiających się ekscerptów, podkreślano, że Słoweńcy cenią umiejętności praktyczne i wiedzę nieformalną (A - 0,5\%, H - 1,5\%): use bolj se ceni neformalno znanje; wiedza teoretyczna, która sprawdza sie w praktyce ma dla nich znaczenie $i$ wartość. Dodatkowo wyodrębnione dwie klasy tematyczne w grupie pozytywnego stosunku Słoweńców do nauki i wykształcenia zawierają wyimki, wysłowione jedynie przez polskich respondentów, którzy zauważyli, że Słoweńcy studia postrzegaja jako etap pomocny w karierze

11 Tego typu wyimki w części autostereotypowej omawianej podklasy stanowią 3\% z 7\%.

$12 \mathrm{~W}$ przypadku popularności języka angielskiego należy również wspomnieć o roli telewizji - niemającej tradycji dubbingowania bajek, filmów czy nawet krótkich wypowiedzi w języku obcym - jako tłumaczenie wykorzystującej napisy na dole ekranu. 
$(\mathrm{H}-2 \%)$ : w dobrym wykształceniu widza klucz do sukcesu; maja plany na prayszłość zwiqzane ze studiami, jakie kończq oraz, że słoweńscy studenci studiują dwa kierunki równocześnie $(\mathrm{H}-2,5 \%)$ : popularne studiowanie dwóch kierunków jednocześnie. Brak tych ostatnich egzemplifikacji w wypowiedziach słoweńskich respondentów może wynikać z tego, że dwukierunkowość jest dla nich oczywista - większość programów studiów w Słowenii jest dwukierunkowa, student ma obowiązek wybrać dwa różne kierunki w ramach swojego programu studiów. Po ich skończeniu dyplom absolwenta zawiera tytuły obydwu wybranych programów, tworząc jedną całość ${ }^{13}$.

\section{Negatywny stosunek Słoweńców do nauki i wykształcenia}

Słoweńscy ankietowani mają negatywny stosunek do nauki i wykształcenia, oceniając je prawie w połowie swoich wypowiedzi niekorzystnie (A - 47\%). Mniej nieprzychylni okazali się polscy respondenci - procent poświadczeń o zabarwieniu pejoratywnym w tej grupie jest mniejszy, choć i tak znaczący $(\mathrm{H}-29 \%)$, również pod względem treści zebrane heterostereotypowe ekscerpty niosą ładunek zwykle mniej wartościujaccy in minus. Zasadniczo konceptualizacje świadczące o negatywnie wartościowanym nastawieniu do kształcenia udało się sprowadzić do dwóch podstawowych modeli: pierwszy to rozbudowany obraz nieambitnego stosunku Słoweńców d o e dukacji, w tym wykaz negatywnych cech osoby uczącej się (A - 20\%, $\mathrm{H}-21 \%$ ), drugi zaś - krytyka systemu edukacji, a także - zdaniem respondentów - typowych schematów mentalnych istniejących w słoweńskim społeczeństwie, które przyswajane są w czasie procesu socjalizacji, a więc również w trakcie zapewnionej przez system nauki (A - 27\%, $\mathrm{H}-8 \%$ ).

W ramach pierwszego obrazu rekonstruowana postawa braku ambicji expressis verbis wyrażająca niecenienie czy niewystarczające docenianie edukacji stanowiła liczny odsetek ekscerptów w autostereotypie (A - 12\%) - tego typu poświadczeń nie zarejestrowałyśmy w wypowiedziach Polaków - różnica w dysproporcji obu ujęć wydaje się znacząca. Do wyrażenia ostrych sądów nierzadko stosowano negację czasownika cenić (słń. ceniti): znanosti in ižobrazbe ne znamo dovolj ceniti; premalo cenimo izobrazbo; izobrazbe ne cenijo prevec. Negatywnie wartościowane nastawienie do słoweńskiego kształcenia werbalizowano również za pomocą adekwatnych przymiotników, np.: zły (słń. slab):

13 Por. artykuły Marii Wtorkowskiej (2013; 2017). 
slab odnos do izobraz̧be, kaj sele do znanosti czy niepoważny (słń. neresen): ne preveč resen. Jako powody niedoceniania edukacji niektórzy wskazywali to, że nauka uznawana jest za nieciekawą i niezrozumiała - ludzie jej nie rozumieją i nie dostrzegają jej wpływu na życie codzienne.

Swoisty odłamek rekonstruowanego nieambitnego słoweńskiego podejścia do edukacji współtworzą rzadko zarejestrowane, choć znaczące, wypowiedzi świadczące o pewnego rodzaju interesowności - zgodnie $z$ takim obrazem Słoweńcy decydują się na podjęcie studiów nie z potrzeby zdobycia wiedzy, ale $\mathrm{z}$ chęci zapewnienia sobie wyższych zarobków w przyszłości14: ne gre toliko za željo po znanju, kolikor za željo po udobnem življenju; izobraz̧ba Slovencem veliko pomeni, predvsem zaradi tega, ker si pod visoko izobrazbo predstavljajo visoke dohodke in ležernejš življenje lub wyłącznie w celu zdobycia odpowiedniego dokumentu: prevelika teža dokončane visoke izobraz̧be na papirju.

Dodatkowo, w nie najczęściej rejestrowanych wyimkach, formułowano swoistą selektywność - poważanie tylko wybranych obszarów nauki15. Taka postawa może wiązać się ze wskazaną interesownością, gdyż „uzasadnione” - głównie z materialnego punktu widzenia - jest wykształcenie, które daje dobre wynagrodzenie, inne - zgodnie z tak przyjętą perspektywą - uznawane jest za "stratę czasu i pieniędzy”, a nawet za „szkodliwe”: do izobraz̧be je odnos tudi selektiven (nekaj strok je „legitimnib”, pa še to povečini z. materialnega stališča, ostale so „izguba časa in denarja”, če ne celo „škodliive”). Zdaniem niektórych respondentów Słoweńcy cenią dopiero te rodzime osiagnięcia naukowe, które uzyskały międzynarodowe uznanie: znanost se ceni, če komu kaj uspe v mednarodnem merilu lub poważaja nauki przyrodnicze, techniczne i medyczne, uznając je za „prawdziwe” i ,jedynie wartościowe”, a nie doceniają nauk humanistycznych lub wręcz uważaja je za zbędne: cenijo predvsem naravoslovne znanosti, družboslovje imajo za neuporabno in izgubo casa; kot ,prava” in ,edina vredna znanost” se tretira zgolj naravoslovna, tehniška, medicinska znanost.

Zdecydowana większość polskich wyimków i dość duża grupa słoweńskich współtworzą sygnalizowany negatywnie wartościowany wycinek obrazu Słoweńca profilowanego jako osoby

14 Wyimki informujące o kierowaniu się chłodną kalkulacją miast pozytywnie ocenianej chęci zdobycia wiedzy stanowią w omawianej podklasie $2 \%$ z $12 \%$.

15 Wybiórczość uznawanych dyscyplin naukowych stanowi łącznie 5\% z 12\% wyimków zebranych w omawianej podklasie ekscerptów świadczących o niewystarczającym cenieniu nauki. Procentowy rozkład materiału to: $1 \%$ - poważanie dopiero międzynarodowych słoweńskich sukcesów naukowych, 3\% - uznanie tylko dla wybranych gałęzi nauki, 1\% - szanowanie tylko tego obszaru, którym ktoś się bezpośrednio zajmuje. 
kształcącej się lub wykształconej, w tym jako (tytułowego) wiecznego studenta (A $-8 \%, \mathrm{H}-21 \%)$.

W części poświadczeń ankietowani wyrazili wprost postrzeganie Słoweńca jako nieambitnego, niepracowitego studenta $(\mathrm{A}-5 \%, \mathrm{H}-5 \%)$ : drugi so pridnejsi; nie sq aż tak ambitni i nastawieni na kariere jak studenci w innych krajach Europy. Ujęcie porównawcze (heterostereotypowe) pokazuje, że z jednej strony inni Europejczycy postrzegani sa jako ambitniejsi niż Słoweńcy, z drugiej zaś - bywa, że w podejściu do nauki (albo przynajmniej do wyboru studiów) Polacy okazują się podobni do opisywanych poludniowych pobratymców: co sie tyczy wykszztatcenia, tutaj jest podobnie jak w Polsce - wsyyscy ida na studia, ale nie kå̀dy wie dlaczego.

Dodatkowo, słoweńscy badani językowo wyrazili pogląd, iż typowy dla ich kraju student może charakteryzować się negatywnie wartościowaną przeciętnością, brakiem kreatywności i indywidualizmu, co wiąże się z opisywaną postawą nieambitną ${ }^{16}$ : ni poudarka na izvirnosti, obstaja moćna zavest ne izspostavljanja se, biti porprečen je vrlina, veliko se kopira in ni izvirnosti. Z kolei, zgodnie z opiniami wyrażonymi przez naszych rodaków, słoweński nieambitny stosunek do kształcenia wynika m.in. z tego, że studenci maja luźne podejście do studiow, bowiem doskonale zdaja sobie sprawe ze swoich praw, chyba troszke zapominajac o obowiazkach i jeśli moga zdecydować między obowiązkiem uczelnianym a przyjemnościa, to wybiorą to drugie: jeśli jest możliwość zrobienia dwutygodniowego wypadu nad morze, to raczej zrobiq to, nawet jeśli jest on w okresie egzaminacyjnym ${ }^{17}$.

Odtworzony obraz nieambitnego podejścia do nauki bezpośrednio wiąże się z mocno utrwalonym w polskim materiale językowym, a symbolicznie w słoweńskim, portrecie Słoweńca konceptualizowanego jako wiecznego studenta (A - 3\%, H - 16\%): problem večnega študenta; wieczni studenci - dtugo studiuja lub maja status studenta. Rodacy Petera Prevca nie kończą studiów terminowo, mocno je wydłużając - taką opinię szczególnie często wyrażali polscy ankietowani, uznając bycie wiecznym studentem za typową cechę studentów w Słowenii1 ${ }^{18}$ : nočejo hitro zaključiti izobrazbe; mnogi dolgo časa študirajo; zaunażalna jest skłonnośc do przeciagania studiów w nieskończoność, przekeładania egzaminow na kolejne sesje itd.; Stoweńcy bardzo dtugo studiuja ciagnac studiowanie w nieskończonośc - wykoraystujac urlop absolwencki, powtarzajac rok itp.; mam wraże-

16 Tego typu ekscerpty w omawianej podklasie stanowią $2 \%$ z 5\%.

17 Opisany miniobraz został językowo wyrażony w części heterostereotypowych wyimków omawianej podklasy $(1,5 \%$ z $5 \%)$.

18 Oto udział procentowy tego typu wyimków: A - 1\% z 8\%, H - 14\% z 16\%. 
nie, że tutaj sie studia nie kończa; nie spieszyli sie z ukończeniem studiów, pržedtużali je, a z.obrona pracy dyplomowej zwlekali nawet kilka lat, mtodzi Stoweńcy robia licencjat przez. 5-10 lat, odwlekanie obrony pracy magisterskiej (zazwyczaj obrona okoto 30 roku ìycia). Konsekwencją bycia wiecznym studentem, swobodnego podejścia do obowiązków względem uczelni, jest częsta (choć rzadko językowo wyrażana przez respondentów) sytuacja, że znaczna część Słoweńców nigdy nie decyduje się na formalne zakończenie studiów, a więc na uzyskanie dyplo$\mathrm{mu}^{19}$.

Obraz zdystansowania wobec funkcjonujacego programu oświaty (i społecznie istniejących schematów mentalnych, które odzwierciedlają się w edukacji i siłą rzeczy przez nią są propagowane) jest złożony, dotyka różnych płaszczyzn. Jak wcześniej wskazano, szczególnie bogato pod względem ilościowym i jakościowym jest możliwy do zrekonstruowania na podstawie danych autostereotypowych (A - 26\%, H - 8\%).

Dość duży odsetek słoweńskich ekscerptów dotyczy krytyki powszechnej dostępności do edukacji oraz jej nieodpłatności, cech pozornie ogólnie uznawanych za pozytywne (A - 9\%): zaradi velike dostopnosti izobrazbe (brezplačna) čedalje manj velja, w tym pojawiania się coraz większej liczby nowych szkół, co zdaniem ankietowanych w konsekwencji prowadzi do obniżania poziomu nauki na każdym szczeblu kształcenia: tudi izobraz̧ba ni preveč cenjena,

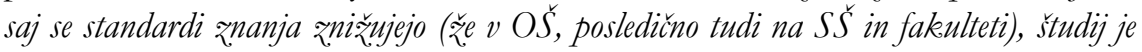
skorajda samoumeven, raznorazne fakultete rastejo kot gobe po deřju. W takim ujęciu rozpoczęcie studiów traktowane jest jako pewnego rodzaju konieczność studia przestały być elitarne, co obniżyło poziom nauczania i prestiż edukacji. Zgodnie z tym sposobem myślenia w słoweńskim społeczeństwie jest za dużo ludzi z wyższym wykształceniem ${ }^{20}$ : preveč visoko izobraženih ljudi. Studia nie sa gwarantem zatrudnienia - brakuje miejsc pracy dla osób w wyuczonym zawodzie, często więc pracownicy mają nieadekwatne wykształcenie do zajmowanego stanowiska ${ }^{21}$ : vsi si želijo studirati, kar je zadnje čase postal problem, saj ni dovolj deficitarnih poklicev; tisti, ki pa končajo šolanje, imajo pa težave pri iskanju službe, saj imajo dostikrat previsoko izobrazbo za določena delovna mesta.

Sporadycznie zarejestrowane ekscerpty tworzą minimodel w pewnym stopniu przeciwstawny $(\mathrm{H}-1 \%, \mathrm{~A}-1 \%)$. W symbolicznie odnotowanym ujęciu heterostereotypowym pojawiły się wskazania świadczące o tym, że

19 Obraz zarysowany symbolicznie: A $-1 \%, \mathrm{H}-1 \%$.

${ }^{20}$ Taki pogląd bezpośrednio został wyrażony w małej grupie autostereotypowych ekscerptów $(2 \%$ z $9 \%)$.

21 Wyimki w tej podklasie stanowią 3\% z 9\%. 
nauka na uczelniach jest w Słowenii mniej popularna, a praca stanowi wartość ważniejszą niż studia. Poza tym nauka, choć powszechna i bezpłatna, jest w opinii jednostkowych słoweńskich respondentów w zbyt małym stopniu wspierana przez państwo.

Liczna grupa słoweńskich wyimków współtworzy zróżnicowany model negatywnie ocenianego braku szacunku dla ludzi wykształconych (A - 12\%). Stanowi to pośrednio krytykę funkcjonujących w społeczeństwie (a więc i bezwiednie aprobowanych) schematów mentalnych. Zgodnie $z$ tak zarysowanym obrazem niecenione są osoby $\mathrm{z}$ wyższym wykształceniem, w tym posiadające tytuły naukowe ${ }^{22}$ : pogosto se poudarja, da se znanstvenikov in strokovnjakov ne ceni dovolj; domače izobražence in znanstvenike se je vedno premalo cenilo. W opinii niektórych badanych zdarza się, że osoby z wykształceniem nie cieszą się poważaniem nawet wśród naukowców: vsi boljsi slovenski znanstveniki v Sloveniji niso zařeleni. Przyczyn ujemnie oceniających sądów o braku szacun$\mathrm{ku}$ wobec ludzi wykształconych respondenci upatruja w specyficznym („słoweńskim”) sposobie myślenia: „w Słowenii każdy może być każdym”, zgodnie z przeświadczeniem, że każdy może być mistrzem (specjalista) nie tylko w swojej, ale w każdej branży: ker v Sloveniji je itak labko vsak vse (miselnost: saj to bi pa tudi jaz labko počel-vsak je mojster vsega) ${ }^{23}$.

Pewna część wyimków rysuje obraz konieczności emigracji - brak zagwarantowania we własnym kraju ludziom dobrze wykształconym właściwej im pozycji i odpowiedniego szacunku zmusza ich do wyjazdu zagranicęe24: vsi boljsi slovenski znanstveniki odhajajo v tujino, v Sloveniji niso zaželeni; večina izobraženih gre delat ven iz domovine; tisti, ki imajo ambicije veřnoma ciljajo na tujino, ker se vsi zavedamo, kako težko je doma uspeti, gdzie maja możliwość rozwijania swoich talentów i umiejętności: talentirani ljudje pogosto odhajajo v tujino, kjer labko bolje razvijajo svoje sposobnosti.

Niewielka grupa słoweńskich ekscerptów symbolicznie współtworzy krytykę innych wskazanych przez respondentów schematów myślenia mieszkańców Słowenii (A - 4\%), często ukrywanych - ujawniających się nie

22 Wskazany syndrom został bezpośrednio wyrażony w połowie wyimków z tej podklasy (A $-6 \%$ z $12 \%$ ).

${ }^{23}$ Dodatkowo, Słoweńcy zauważają również, że często pracodawcy nie cenią wykształconych pracowników, ponieważ albo zmuszeni są dać im wyższe wynagrodzenie, albo boją się konkurencji z ich strony. Problematyczność zatrudniania osób o wysokich kwalifikacjach stanowi jednak symboliczny odłamek w omawianej podklasie (A - 1\% z 12\%).

${ }^{24}$ Model zrekonstruowany z prawie połowy egzemplifikacji w omawianej podklasie (A - 5\% z $12 \%$ ). 
wprost, oficjalnie niemających przyzwolenia. Jednym z nich jest społeczne postrzeganie osoby niewykształconej za mniej wartościową: tisti manj izobraženi pa so žal večkrat dojeti kot manjuredni; manjureden odnos do useh ne-gimnazijskih srednješlskih programov. Takie deprecjonujące podejście może łączyć się z krytykowanym przyzwalaniem na rewaluację osób posiadających wykształcenie i/lub wyższą pozycję 25 : elitističen (izobraz̧bena stopnja kot glavno merilo intelektualne sposobnosti ali družbene vrednosti), znotraj organizacij in strok bierarbičen (višja stopnja ali naslov „daje pravico” zlorabljati use pod sabo). Zgodnie z takim ujęciem miarą społecznej wartości człowieka jest głównie poziom wykształcenia lub tytuł naukowy, które niejako „dają prawo” do wykorzystywania podwładnych - co w opinii niewielkiej części badanych jest zjawiskiem powszechnym, nie tylko ograniczającym się do środowiska ludzi nauki.

$\mathrm{Na}$ inne aspekty słoweńskiego systemu edukacji krytycznie spojrzeli polscy ankietowani - jak sygnalizowano, skoncentrowali się na wskazaniu przyczyn bycia wiecznym studentem (H-7\%), zjawiska, zdaniem respondentów, typowego w Słowenii. Zgodnie z odtworzonym heterostereotypowym obrazem mieszkańcy kraju nad Sawą, Drawą i Murą często decydują się na studia lub wydłużają je z powodu profitów płynących ze statusu studenta - zniżki na różne bilety, tańsze obiady (nie tylko w stołówkach, ale i w bardziej ekskluzywnych restauracjach) czy możliwość podjęcia pracy za pośrednictwem specjalnych serwisów studenckich: ze wagledu na udogodnienia plynace z posiadania statusu studenta okres nauki zazwyczaj sie uydtuża; ze wagledu na udogodnienia przedtuzaja studia „w nieskończonośc”, innymi słowy: ze wagledu na trudna sytuacje finansowa (potrzebe posiadania statusu studenta) wola być wiecznymi studentami. Powyższe wypowiedzi sa pośrednią krytyką systemu socjalnego i edukacyjnego, który pozwala(1) na takie rozwiązania. Expressis verbis wyraża to jedna z respondentek: myśle, że prayczyna tego nie by to jedynie podejście studentów do nauki, ale system szkolnictwa, który to umożliwiat26.

W odróżnieniu od polskich respondentów, słoweńscy ankietowani nie werbalizowali przywilejów socjalnych przysługujących studentom i stano-

25 Ten symbolicznie zarysowany model stanowi swoiste odwrócenie opisanego wcześniej (poświadczonego w zebranym materiale) obrazu Słoweńca wykształconego, a niecenionego.

${ }^{26}$ Niektórzy respondenci dostrzegają, że czas beztroskiego przedłużania studiów powoli mija, gdyż coraz trudniej jest młodemu człowiekowi - pomimo wszystkich ulg, które niesie ze sobą status studenta - utrzymać się bez pomocy rodziców, na którą niejednokrotnie, szczególnie w ostatnich latach kryzysu w Słowenii, niestety nie mógł liczyć: studenci jesz̧cze pare lat temu robili, co wich mocy, by studiować jak najdtu̇iej, na kilku kierunkach. Teraz warunki sq trudniejsze, trzeba sqybciej zaczać prace, bo ciężj sie utraymać. 
wiących jedną z głównych przyczyn wydłużania czasu studiów - być może są one tak oczywiste dla uprawnionych do nich, że aż są niezauważalne i niewarte wspomnienia.

\section{Inne}

W ostatniej grupie wypowiedzi (A - 3\%, H - 8\%) znalazły miejsce werbalizacje, których nie można było jednoznacznie zaliczyć do wartościujących pozytywnie lub negatywnie.

Zarówno słoweńscy, jak - nieco liczniej - polscy badani (A - 1,5\%, H - 5\%), ujawniali problem z określeniem stosunku Słoweńców do nauki i wykształcenia, przeważały więc egzemplifikacje wyrażające niewiedzę na ten temat: ne vem; trudno stwierdzić, nie wiem. Niektórzy wysłowili swój stosunek do nauki i wykształcenia jako zależny od człowieka: odvisno od osebe; zdecydowanie podzieleni w tej kwestii, też jako ambiwalentny: kar se izobrazbe tiče, veliko damo na izobraz̧bo, veliko pa se jih tudi odloči, da bodo po srednji soli sli delat. Wyłącznie polscy ankietowani zauważali pozytywnie oceniane zainteresowania Słoweńców $(\mathrm{H}-3 \%)$, jak ciekawość świata i umiłowanie podróży, stanowiące swoisty rezultat stosunku do wiedzy i edukacji: maja różnorodne zainteresowania, sq ciekawi swiata, duźo podróżuja, a dwoje słoweńskich ankietowanych zwerbalizowało niedostrzeganie niczego, co wyróżniałoby ich stosunek do nauki i wykształcenia od innych, określając go neutralnie jako normalny: normalno.

Do kategorii 'inne’ włączono również brak odpowiedzi (A - 1,5\%, H - 0\%), uznając ten fakt za istotny, między innymi dlatego, że to wyłącznie czworo słoweńskich badanych, a więc ludzi, którzy z założenia powinni znać swój system edukacji, zdecydowało się na nieudzielenie odpowiedzi na temat stosunku do nauki i wykształcenia. Brak odpowiedzi może zatem wiązać się z dystansem do systemu edukacji (a nie brakiem wiedzy na ten temat) lub uznaniem tego pytania za nieistotne (w opinii respondentów).

Nauka i kształcenie są fundamentem kultury stanowiącej całokształt materialnego i duchowego dorobku człowieka, a także - jak stwierdza Nahtigal zwieńczeniem kulturowego rozwoju każdego narodu: „V kulturnem razvitku vsakega naroda se znanost na splošno pojavlja najpozneje, je zato vrh kulture in neobhodni znak končne kulturne dozorelosti in resnično kulturnega nivoja kakega naroda" (Nahtigal 1927, 11). Analiza danych językowych z wykorzystaniem kategorii operacyjnych językowego obrazu świata pozwo- 
liła na odtworzenie słoweńskiej postawy względem nauki i wykształcenia z punktu widzenia ankietowanych Polaków i Słoweńców, wyodrębnienie cech istotnych i marginalnych, cenionych, ganionych oraz neutralnych, a raczej niejednoznacznych pod względem wartościowania.

Podsumowując, połowa zebranych autostereotypowych ekscerptów oraz większość wyimków w ujęciu heterostereotypowym, stosunek Słoweńca do nauki i wykształcenia kreśli jako wyraźnie pozytywny. Nauka i wykształcenie przedstawiają dla Słoweńców wartości ważne i istotne, mieszkańcy Słowenii cenią edukację oraz ludzi wykształconych, zwłaszcza posiadających tytuł naukowy. Jedynie w modelu zarysowanym na podstawie słoweńskich ankiet językowo wyrażono, dodatnio wartościując, ogólnodostępność i bezpłatność szkolnictwa oraz podkreślono wysoki poziom nauczania, z którego są dumni mieszkańcy kraju ${ }^{27}$. Słoweniec to w oczach swoich oraz polskich badanych człowiek wykształcony, skory do nauki, pracowity, pilny, sumienny, ambitny, postępowy i otwarty. Z ekscerptów obu badanych grup wynika, że Słoweniec doskonale zna języki obce, w tym biegle język angielski, którym na podobnym poziomie posługuje się zarówno profesor, jak i bezdomny żebrak. Jedynie polscy ankietowani językowo wyrazili - oczywisty ze słoweńskiej perspektywy - fakt, że Słoweniec studiuje jednocześnie dwa kierunki. Głównie polscy respondenci chwalili słoweńską oświatę i słoweńskich wykładowców, podkreślając ich mniej formalne podejście w kontakcie ze studentami oraz umiejętność zaciekawienia swoim przedmiotem.

Obraz kreślący przeciwstawna postawę, a więc krytyczny stosunek Słoweńców do nauki i wykształcenia, odtworzony został zadziwiająco mocno, zarówno pod względem częstotliwości, jak i jakości danych. Słoweńscy ankietowani okazali się bardzo krytycznymi obserwatorami. Wypowiedzi heterostereotypowe były nieco rzadsze, zwykle niosły też mniejsze zabarwienie emocjonalne. Negatywnie wartościowany stosunek do słoweńskiego kształcenia współtworzą dwa podstawowe modele. Pierwszy to rozbudowany obraz nieambitnej postawy względem edukacji, w tym rekonstrukcja odpowiednio profilowanego kształcącego się lub wykształconego Słoweńca, cechującego się brakiem ambicji i pracowitości. Polscy respondenci postrzegaja go jako wiecznego studenta mocno wydłużającego studia (a nawet ich niekończącego), uznając to za rys typowo słoweński. Słoweniec doskonale zdaje sobie sprawę z korzyści posiadania statusu studenta (znaczne

27 Polemiczne nastawienie (załamanie takiego wizerunku) jest jednak mocno widoczne w autostereotypowym ujęciu krytycznym. 
zniżki, dostępność pracy itd.), nie troszcząc się przy tym o obowiązki względem uczelni.

Drugi negatywnie wartościowany model stanowi krytykę systemu edukacji i związanych z nim schematów mentalnych - szczególnie surowy osąd wyłania się z perspektywy autostereotypowej. Tylko Słoweńcy językowo wyrazili wprost to, że ich stosunek do nauki i edukacji jest nieambitny; zdarza im się, że podejmują studia ze względu na różne korzyści, cenią wybrane (zdecydowanie niehumanistyczne) gałęzie nauki oraz te, którymi sami się zajmują są przekonani, że w Słowenii każdy może być specjalistą w każdej dziedzinie. Zdaniem mieszkańców kraju nad Sawą, Drawą, Murą i Soczą często w ich kraju nie ceni się osób z wyższym wykształceniem ani osób zajmujących się pracą naukową, co z kolei wiąże się z emigracją zarobkową dobrze wykwalifikowanej kadry.

Zdecydowanie mocniejszy krytycyzm w ujęciu autostereotypowym z pozoru może wydać się nietypowy - schematy myślowe dotyczące własnej grupy nierzadko tworzą się w kontekście porównawczym z inną grupa, co z kolei może wiązać się z niebezpieczeństwem przeceniania własnej wartości („wybielania się”) często kosztem pomniejszenia oceny „innego”, bo „nie swojego" (por.: Panasiuk 1998, 93). Wysoki odsetek samokrytycznych słoweńskich odpowiedzi wynika w jakiejś części z perspektywy przyjętej przez objętą badaniem grupę - nierzadko ludzi młodych, będących w trakcie studiów lub po nich, którzy na co dzień zderzają się ze słoweńską rzeczywistością i perspektywami pracy, nie w pełni odpowiadającymi ich aspiracjom i kwalifikacjom. Ocena Słoweńców jest bardziej wnikliwa, co zrozumiałe, bo wyrosła na szerszych (mniej schematycznych) bezpośrednich doświadczeniach; poza tym słoweńskie ujęcie wiąże się z uzależnioną kontekstowo postawą binarną - cenienia własnej wartości versus niecenienia się (obniżania swojej wartości) - co można uznać za jedną z cech narodowych (typowo słoweńskich, ale i typowo polskich), a może i ogólnoludzkich (wspólistnienie postawy wysoko oceniającej walory własne i swojego kraju wraz z podejściem przeciwstawnym).

Stereotyp wiąże się nierozerwalnie z językiem, jego rola w kształtowaniu określonej (właściwej danej grupie) wizji świata, postaw i zachowań jest ogromna (Bartmiński, Panasiuk 2001, 374). Analiza danych ankietowych pozwoliła zrekonstruować modelowe wyobrażenie tego, w jaki sposób słoweńscy i polscy badani, postrzegają stosunek Słoweńców do nauki i wykształcenia przez pryzmat własnego języka, zauważając i uwydatniając, zgodnie z własną perspektywą, odpowiednie aspekty. Cechy te składają się na wyob- 
rażenie najbardziej typowego reprezentanta grupy obiektów. Jest to obraz uproszczony, schematyczny $\mathrm{i}$ intersubiektywny.

\section{Literatura}

Bartmiński J., 2007, Stereotypy miesžkaja w jesyku. Studia etnolingwistyczne, Lublin.

Bartmiński J., 2009, Jesylkowe podstawy obrazu swiata, Lublin.

Bartmiński, J., Bielińska-Gardziel I., 2012, Polski jesylkowo-kulturony obraz domu (c₹: I), w: Abramowicz M., Bartmiński J., Bielińska-Gardziel I., red., Wartości w jesykowo-kulturowym obrazie swiata Stowian i ich sasiadón, t. 1, Lublin.

Bartmiński J., Panasiuk J., 2001, Stereotypy jesylkowe, w: Bartmiński J., red., Wspótczesny jezylk polski, Lublin.

Krek J., Metljak M., red., 2011, Bela knjiga o vagoji in ižobraževanju v Republiki Sloveniji, Ljubljana.

Medveš Z., 1999, Šolstvo, w: Voglar D. (red. naczelny), Dermastia A. (red. tomu), Enciklopedija Slovenije, t. 13: Š-T, Ljubljana.

Nahtigal R., 1927, Nekaj kratkih pripomb o pomenu, potrebi in nalogah Akademije znanosti v Ljubljani. Naša največja kulturna naloga, w: Akademija znanosti in umetnosti, Narodna Galerija, Ljubljana.

Panasiuk J., 1998, O żmienności stereotypów, „Język a Kultura”, t. 12, Anusiewicz J., Bartmiński J., red., Stereotyp jako przedmiot lingwistyki: teoria, metodologia, analisy empiryczne, Wrocław.

Wacławek M., Wtorkowska M., 2017a, „Stowiański góral spod Alp” - z badan nad auto- $i$ beterostereotypem Stoweńca, w: Vojteková M., red., Jasylk v kultuire, kultúra v jasylku. Jesylk w kulturze, kultura w jesyku, Prešov.

Wacławek M., Wtorkowska M., 2017b, „Stowianski Austriak” - o charakterze Stoweńców stón kilka, ,Jezikoslovni zapiski”, nr 1, Ljubljana.

Wacławek M., Wtorkowska M., 2017c, Stoweńcón spedzanie wolnego czasu - w kregu badań jezy)kowo-kulturonych stereotypów, w: Kołodziej A., red., Piasecki T. (współpraca), Stowiańszçyyzna dawniej i driś-jesylk, literatura, kultura. Monografia ze studión slawistycznych III, Červený Kostelec.

Wacławek M., Wtorkowska M., 2018a, Cztowiek człowiekowi lustrem - konceptualizacje Polki i Polaka w mypowiedziach polskich i stoweńskich respondentón, w: Wtorkowska M., Wacławek M., Rezoničnik L., red., Sedemdeset let poučevanja poljskega jezika v Ljubljani, posvečeno Nikolaju Jě̌u, Ljubljana.

Wacławek M., Wtorkowska M., 2018b, „Jak ich widzq, tak ich piszq” - rzecz o uygladzie Stoweńcón, w: Tambor J., red., Polonistyka na poczatku XXI wieku. Diagnozy. Koncepcje. Perspektywy, t. 4: Pogranicza, mniejszości, regiony. Etnolingwistyka, Katowice.

Wacławek M., Wtorkowska M., 2018c, Powiedz mi, co jesz, a powiem ci, kim jesteś - o kulinariach w Stowenii, w: Grochala B., Dembowska-Wosik I., red., „Acta Universitatis Lodziensis. Kształcenie Polonistyczne Cudzoziemców”, nr 25, Łódź.

Wacławek M., Wtorkowska M., 2018a [w druku], Przez jedzenie do jesykea... polskiego - o kulinariach oczami Polakón i Stoweńcón, w: Lech-Kirstein D., red., Bariery i pomosty w jesyku i kulturze, Opole.

Wacławek M., Wtorkowska M., 2018b [w druku], Caas wolny Polakón - w kregu jesykeowo-kulturowych stereotypón, w: Lech-Kirstein D., red., Bariery i pomosty w jesylku i kulturze, Opole. 
Wacławek M., Wtorkowska M., 2019c [w druku], „Nasz wyglad zależy od tego, w jakim lustrze sie prajirymy"- z badań nad stereotypem Polaka, Zagreb.

Wacławek M., Wtorkowska M., 2019d [w druku], Smaki Stowenii - o kulinariach w ujeciu autostereotypowym, w: red. B. Mitrenga, „Linguarum Silva”, Katowice.

Wacławek M., Wtorkowska M., [w opracowaniu], Polaków stosunek do edukacji - w kregu jezykowo-kulturowych stereotypów, „Z Teorii i Praktyki Dydaktycznej Języka Polskiego”, Katowice.

Wtorkowska, M., 2013, Polonistyka i nowe programy studiów na slawistyce w Lublanie, w: Mazur, J., Małyska, A., Sobstyl, K., red., Glottodydaktyka polonistyczna w obliczu dynamiki zmian jezykowo-kulturowych i potrzeb społecznych, Lublin.

Wtorkowska, M., 2017, Od lektorata do studijske smeri - ob deseti obletnici ustanovitve bohemistike, polonistike in slovakistike na Filozofski fakulteti v Ljubljani, „Jezik in slovstvo”, 62/2-3. 